\title{
Akurasi Arah Kiblat Masjid di Ruang Publik
}

\author{
Anisah Budiwati ${ }^{1}$, Saiful Aziz ${ }^{2}$ \\ 1,2Universitas Islam Indonesia \\ Corresponding e-mail : ${ }^{1}$ anisah.budiwati@uii.ac.id, ${ }^{2}$ saifulaziz.albantany@gmail.com
}

\begin{abstract}
This research explores the concept of understanding of mosque managers in the public space about the importance of facing the direction of Qibla. Samples Mosque located in the public space of the Hospital Jogja International Hospital, Adisutjipto Airport and Mall Plaza Ambarrukmo be proof of the tendency of pattern of understanding of managers of religious orders to face the direction of Qiblah correctly. By using qualitative analysis method and data collection method in the form of observation, interview and documentation, it is found that first, that understanding of mosque managers in public space at three places reflects the quality of life of Islami ie measuring to the expert so that the direction of qibla. Secondly, the accuracy of the direction of the mosque building in the public space in Sleman Yogyakarta is included in the category of accurate with the maximum reason for the 6 minute arc disturbance, where the direction of the largest deviation on the mosques is 0 o 1 '20.8 "or equivalent to $3,074 \mathrm{~km}$ which means still leads the city of Mecca.
\end{abstract}

Keyword: Accuracy, Understanding and Mosque in public space

Abstrak Penelitian ini menggali konsep pemahaman para pengelola Masjid di ruang publik tentang pentingnya menghadap arah kiblat. Sampel Masjid yang berada di ruang publik yakni Rumah Sakit Jogja International Hospital, Bandara Adisutjipto dan Mall Plaza Ambarrukmo menjadi bukti kecenderungan pola pemahaman pengelola terhadap perintah agama untuk menghadap ke arah kiblat dengan tepat. Dengan menggunakan metode analisis kualitatif dan metode pengumpulan data berupa observasi, wawancara dan dokumentasi diperoleh hasil penelitian, pertama bahwa pemahaman para pengelola masjid di ruang publik pada tiga tempat tersebut mencerminkan kualitas hidup Islami yakni melakukan pengukuran kepada pihak ahli sehingga arah kiblat sesuai dengan keilmuan astronomi. Kedua, akurasi atau ketelitian arah kiblat bangunan Masjid di ruang publik di Sleman Yogyakarta termasuk dalam kategori akurat dengan alasan maksimal penyimpangan 6 menit busur, di mana arah penyimpangan paling besar pada masjid-masjid tersebut adalah 0o 1' 20,8' atau setara 3,074 km yang berarti masih mengarah kota Mekah.

Keyword: Akurasi, Pemahaman dan Masjid di Ruang Publik

Submited: 15 Januari 2018 Accepted:25 Maret $2018 \quad$ Published:28 Maret 2018

\section{PENDAHULUAN}

Penelitian mengenai arah kiblat di Indonesia sudah tergolong cukup banyak, dari mulai membahas teori perhitungan, akurasi metode pengukuran (Jaelani,
Ahmad, 2012), modifikasi peralatan pengukuran (Hakim, Raharjo, \& Waluyo, 2013), pengukuran kiblat musholla (Kresnadjaja \& Muttaqien, 2014) maupun penelitian pada metode pembelajaran yang terkait erat dengan penentuan arah 
kiblat (Budiwati, 2015), namun selain dari pengamatan penulis terhadap penelitian arah kiblat Masjid-Masjid kuno di beberapa daerah di Indonesia, satu hal yang terlewat dari banyak penelitian arah kiblat Masjid atau Mushola yakni arah kiblat yang ada pada ruang public*). Dalam realita di lapangan, justru ditemukan banyak arah kiblat ${ }^{* *}$ Mushola di ruang publik yang kurang mendapat perhatian khususnya belum menghadap ke arah kiblat seharusnya ${ }^{* * *}$.

Sebagai contoh arah kiblat di ruang publik dapat kita lihat di Provinsi Daerah Istimewa Yogyakarta yang merupakan salah satu provinsi padat penduduk di Indonesia yang menempati urutan ketiga setelah Provinsi DKI Jakarta (13.344 jiwa/km2) dan Jawa Barat (1.126 jiwa/km2) dengan jumlah penduduk mencapai 980 jiwa/km2 pada tahun 2000, yang berarti pada tahun 2000 setiap $1 \mathrm{~km} 2$ wilayah dihuni 980 jiwa (BPS, Hasil sensus penduduk 1961, 1971, 1980, 1990, 2000 dan 2010). Dalam pengamatan penulis, Kabupaten Sleman Yogyakarta yang memiliki luas sebesar 574,82 km2 berpotensi untuk diidentifikasi terkait arah kiblat pada tempat shalat di ruang-ruang publik mengingat Yogyakarta memiliki mobilitas sosial yang tercermin pada kehidupan keagaamaan berupa rumah ibadah (Goenawan, 2012). Sebagaimana data BPS DIY 2014 juga menyebutkan Sleman memiliki status perkotaan paling banyak dibandingkan kabupaten lainnya (BPS, 2015).***) Sehingga, wilayah ini lebih banyak memiliki ruang publik yang tentunya berbanding lurus dengan jumlah penduduknya. Selain itu, keperluan untuk menghadap kiblat secara tepat adalah suatu keniscayaan di zaman majunya teknologi seperti saat ini. Sehingga kajian tentang arah kiblat di tempat-tempat ibadah di ruang publik ini menjadi sangat penting untuk diidentifikasi dan diberikan penjelasan mengenai akurasi arah bangunannya.

Jika memperhatikan pendirian bangunan di ruang-ruang publik seperti Rumah Sakit, Restoran, Kebun Binatang, Terminal, Stasiun, Mall dan Pom Bensin, penulis melihat bahwa keperluan ibadah umat muslim untuk shalat di negara kita sudah terfasilitasi dengan baik, salah satunya sudah tersedianya ruangan khusus.

*) Dalam (Carmona, Tiesdell, Carmona, \& Heath, 2003) disebutkan penjelasan ruang lingkup yang dibagi menjadi beberapa tipologi antara lain : External public space. Ruang publik jenis ini biasanya berbentuk ruang luar yang dapat diakses oleh semua orang (publik) seperti taman kota, alun-alun, jalur pejalan kaki, dan lain sebagainya. Internal public space. Ruang publik jenis ini berupa fasilitas umum yang dikelola pemerintah dan dapat diakses oleh warga secara bebas tanpa ada batasan tertentu, seperti kantor pos, kantor polisi, rumah sakit dan pusat pelayanan warga lainnya. External and internal "quasi" public space. Ruang publik jenis ini berupa fasilitas umum yang biasanya dikelola oleh sektor privat dan ada batasan atau aturan yang harus dipatuhi warga, seperti mall, diskotik, restoran dan lain sebagainya.

**) Arah kiblat dimaknai sebagai arah terdekat dari seseorang menuju Kakbah (Izzuddin, 2012).

***) Dari survei penulis beberapa waktu lalu ketika mengunjungi pusat perbelanjaan di Kab. Sleman masih terdapat musholla Swalayan yang kurang memadai dikarenakan ruangan sempit, tidak terawat dan tidak ada tanda kiblat kecuali pigura Kakbah, padahal musholla di ruang publik lainnya seperti di pengisian Pom Bensin sangat tertata, bersih dan tertera tanda kiblat yang jelas

****) Menurut data BPS DIY tahun 2014, status perkotaan untuk 5 kabupaten di Yogyakarta yaitu: Kulonprogo berjumlah 13, Bantul berjumlah 47, Gunung Kidul berjumlah 5, Sleman berjumlah 59 dan Yogyakarta berjumlah 45 . 
Penataan sederhana didasarkan pada ketersediaan seadanya, diantaranya pakaian shalat yang terdiri dari sarung, sajadah, mukena atau al-Qur'an dan gambar Kakbah sebagai petunjuk arah kiblat. Sedangkan penataan istimewa dapat didasarkan pada adanya penyediaan sarana prasarana lengkap ditambah dengan pengelolaan Masjid yang secara tertib dilaksanakan.

Sepanjang pengetahuan peneliti, mayoritas penelitian terkait ruang publik terbatas pada fungsinya sebagai sarana interaksi masyarakat (Anita, Gustya, Erawati, \& Sukma, 2012), tingkat kualitas lingkungan hidup yang berwujud pada bangunan yang efisien energi dan berkonsep green architecture, sedangkan bangunan dengan kualitas hidup Islami yakni memaksimalkan dan mengoptimalkan fungsi tempat ibadah yakni mushola masih terabaikan. Sebagian besar masyarakat di sekitar kita terlihat masih mementingkan hunian yang berpengaruh pada lingkungan dan manusia, namun kurang tertarik pada persoalan agama. Padahal melihat perintah agama yakni menghadap arah kiblat ketika shalat adalah salah satu syarat yang wajib dipenuhi. Menghadap arah kiblat merupakan hal yang sangat urgen bagi pelaksanaan ibadah umat Islam, sebagaimana kesepakatan para ulama (Al-Qurtuby, n.d.) dalam Bidayat alMujtahid wa Nihayat al-Muqtashid bahwa menghadap ke arah kiblat merupakan salah satu syarat penentu keabsahan shalat.

Penataan ruang publik kota sebagai ruang konsensus warga menjadi indikator sejauh mana proses transformasi konsepsi urbanitas warga kota terbentuk (Sunaryo, Rony Gunawan and Soewarno, Nindyo and Ikaputra, Ikaputra and Setiawan, 2010), maka menjadi penting untuk mengetahui konsep nilai tentang proses transformasi warga terhadap nilai-nilai religi yakni tempat ibadah. Sehingga diperlukan kajian terhadap kecenderungan pola pikir masyarakat terhadap arah kiblat mushola di ruangruang publik. Sehingga penelitian ini dapat memberikan sumbangsih model kualitas hidup Islami umat muslim di Kabupaten Sleman Yogyakarta dalam wujud standar arah kiblat tempat ibadah berupa Masjid di ruang publik yang mengarah ke Kakbah di Mekah secara benar dan tepat sesuai dengan keilmuan astronomi.

\section{METODE PENELITIAN}

Penelitian ini termasuk pada jenis penelitian lapangan (field research), di mana penelitian dimaksudkan untuk mengetahui pemahaman masyarakat khususnya pengelola tempat ibadah di ruang publik tentang penentuan arah kiblat. Penelitian ini dilakukan dengan metode analisis data kualitatif (Kaelan, 2010) di mana akan dicari dan diklasifikasikan terkait definisi ruang ibadah dalam hal ini mushola atau Masjid pada ruang publik untuk kemudian digali semua informasi terkait kondisi pembangunan awal dan akurasi dari arah kiblat bangunannya. Dalam penelitian ini dilakukan analisis sosiologis terhadap pemahaman masyarakat (Ratna, 2010) khususnya pengelola musholla terhadap penentuan arah kiblat sehingga diketahui alasan-alasan mendasar atau faktor-faktor penyebab terhadap kondisi arah kiblat pada mushola di ruang-ruang publik.

Selanjutnya dianalisis penyebab dan faktor yang mempengaruhi pemahaman pengelola musholla mengenai persoalan arah kiblat. Untuk dapat menganalisis akurasi dari masjid di setiap ruang publik, peneliti menggunakan Mizwalla untuk mengetahui sudut kiblatnya dan menggunakan perhitungan trigonometri 
(Smart, 1977) untuk mengetahui sudut penyimpangan pada lantai Masjid di ruang publik tersebut.

Adapun metode pengumpulan data berupa observasi, wawancara dan dokumentasi. Penelitian ini dibatasi pada tiga ruang publik di Kabupaten Sleman Yogyakarta yaitu Masjid di Rumah Sakit JIH (Jogja International Hospital), Bandara Adisutjipto dan Mall Ambarrukmo Plaza.

\section{HASIL DAN PEMBAHASAN}

\section{A. Pemahaman pengelola Masjid di ruang publik}

Untuk dapat menguraikan pemahaman pengelola tempat ibadah terhadap arah kiblat di ruang publik, peneliti memaparkan identitas dan sejarah pembangunan Masjid yang kemudian diberikan kesimpulan atas pemahaman pengelola Masjid di ruang publik yakni di Rumah Sakit JIH, Bandara Adisutjipto dan Mall Amabarukmo Plazza.

\section{Identitas dan sejarah}

\section{Pembangunan Masjid di Ruang Publik}

\section{a. Masjid di Rumah Sakit JIH}

Rumah Sakit JIH yang merupakan kepanjangan dari Jogja International Hospital berlokasi di Jl. Ring Road Utara No. 160, Condong Catur, Depok, Sleman, Daerah Istimewa Yogyakarta. Rumah Sakit ini didirikan berdasarkan Akta Pendirian PT. UMF No.: 33 tanggal 24 Februari 2005, dan telah mendapatkan pengesahan dari Departemen Hukum dan HAM RI No. C17298 HT.01201.TH 2005 tanggal 22 Juni 2005, serta telah diumumkan dalam Lembaran Berita Negara No. 84 tahun 2005 Tambahan Lembaran No. 11273, termasuk di dalamnya Jogja International Hospital sebagai Unit Usaha PT. UMF ("Sejarah Rumah Sakit JIH," 2013).

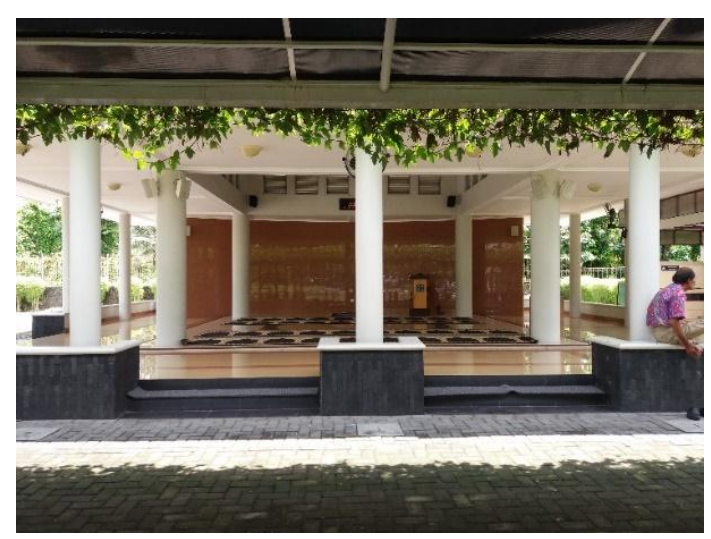

Gambar 1. Masjid terbuka Rumah Sakit JIH yang asri (sumber: penulis)

Ukuran Masjid yang didesign minimalis, artistik, serta elegan ini memiliki luas $\pm 196 \mathrm{~m} 2 / 14 \mathrm{~m} \times 14 \mathrm{~m}$. Di depan Masjid, terdapat ruang publik/umum sebagai tempat bagi para narasumber yang hendak bersiapsiap/beristirahat setelah mengisi kajian di Masjid ini. Selain itu, di depan Masjid pun terdapat gudang yang berisi peralatanperalatan ibadah yang diperuntukkan bagi kemaslahatan Jama'ah Masjid RS "JIH". Masjid ini sengaja dibuat terbuka, agar para jama'ah dapat menikmati indahnya suasana alami di sekitar Masjid tanpa cahaya buatan.

Dalam masjid ini telah disediakan pakaian shalat yang terdiri dari sarung, sajadah, mukena dan al-Qur'an serta gambar Kakbah sebagai petunjuk arah kiblat. Berdasarkan hal tersebut, tatanan ruang masjid ini tergolong memiliki penataan yang istimewa, karena di dalamnya telah tersedia sarana prasarana lengkap ditambah dengan pengelolaan Masjid yang secara tertib dilaksanakan.

Masjid ini pun memiliki tempat khusus yang digunakan tatkala Jama'ah shalat Masjid RS "JIH" melebihi kapasitas yang disediakan, yaitu dengan menggunakan tiang penyangga yang didesign agar tanaman-tanaman rambat dapat tumbuh mengelilinginya sebagai atap alami yang meneduhkan jama'ah serta menambah suasana artistik Masjid tersebut. Tempat 
khusus ini mampu menampung jama'ah hingga lima shaf tambahan.

Sejak awal pendiriannya, arah kiblat Masjid ini telah diukur oleh tim Arah Kiblat yang menghasilkan keputusan untuk mengarahkan bangunan Masjid yang menyelisihi arah jalan di sekitar Rumah Sakit JIH pada umumnya. Hal ini dapat diketahui dari arah bangunan yang sedikit condong ke arah Utara (atau lebih tepatnya ke arah Barat Laut), serta arah bangunan yang tidak sama dengan arah jalan utama Rumah Sakit JIH yang diprioritaskan untuk menghadap ke arah Barat.

Menurut Takmir Masjid RS "JIH", penentuan arah kiblat merupakan hal yang penting. Sehingga tatkala kita hendak menunaikan shalat, sudah sepatutnya kita memperhatikan arah kiblat semampunya agar sesuai dengan apa yang diperintahkan Allah di dalam alQur'an. Menanggapi hal ini, pihak Rumah Sakit pun telah meletakkan tanda isyarat Kiblat pada tiap-tiap ruangan guna memfasilitasi kaum Muslimin yang tidak mampu shalat berjama'ah di Masjid yang telah disediakan Rumah Sakit JIH. Tanda isyarat Kiblat tersebut telah disesuaikan dengan arah kiblat yang searah dengan arah kiblat pada Masjid RS "JIH". .)

Menurut kesaksian Takmir Masjid RS "JIH", selama ini belum pernah dilakukan penelitian ulang arah kiblat yang dilakukan oleh tim khusus. Karena memang pada awal pembangunannya, arah kiblat Masjid ini sudah disesuaikan dengan arah kiblat yang diukur oleh tim
Arah Kiblat. Pernah suatu waktu, ia bersama beberapa rekannya hendak memastikan ulang arah kiblat pada saat terjadi peristiwa Rashdul Qiblah ${ }^{* *}$. Namun amat disayangkan, pada saat yang bersamaan cuaca di beberapa daerah Yogyakarta mendung yang membuatnya terhalang untuk memastikan ulang arah kiblat di Masjid RS “JIH".***)

\section{b. Masjid di Bandara Adisutjipto}

Bandara Adisutjipto adalah bandar udara yang terletak di Sleman, Daerah Istimewa Yogyakarta. Bandar udara ini dulu dinamakan Maguwo, sesuai dengan nama desa tempatnya berada (Maguwoharjo). Penggantian nama dilakukan setelah pesawat Dakota VTCLA yang dikemudikan oleh Marsekal Muda Anumerta Agustinus Adisutjipto ditembak jatuh oleh pesawat Belanda tanggal 29 Juli 1947 ("Sejarah Bandara Internasional Adisutjipto Yogyakarta," 2015).

Di sisi utara bandara ini terdapat sebuah Masjid yang berdiri megah seluas $\pm 256 \mathrm{~m} 2 / 16 \mathrm{~m} \times 16 \mathrm{~m}$. Uniknya, Masjid ini telah mengalami masa transformasi sebanyak 3 kali. Pada awal pembangunannya, Masjid ini terletak di sebuah perkampungan masyarakat Maguwoharjo yang dirancang dengan desain yang sangat sederhana. Namun seiring berjalannya waktu, desain Masjid ini dikembangkan dan disesuaikan dengan keberadaan parkir bandar udara dan rel Kereta Api yang diletakkan beriringan.

*) Hasil wawancara dengan Budi Muljono, S.T. (Ketua Takmir Masjid RS “JIH” periode 2011-2014) pada tanggal 11 Agustus 2016.

**) Rashdul Qiblat adalah metode pengukuran arah kiblat menggunakan arah bayangan matahari pada jam tertentu (Khazin, 2004). Penentuan kiblat dengan metode ini menggunakan benda vertikal baik berupa tongkat atau bisa juga memanfaatkan dinding tiang Masjid yang ada pada teras Masjid.

***) Hasil wawancara dengan Budi Muljono, S.T., 


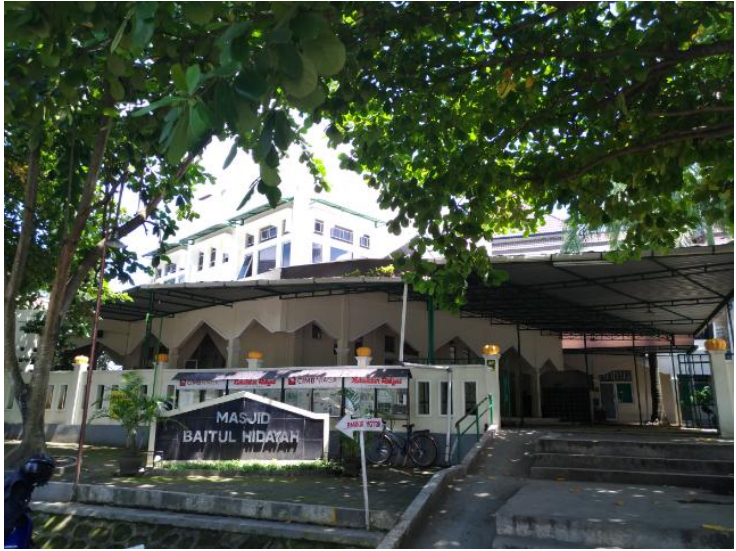

Gambar 2. Masjid Baitul Hidayah Bandara Adisutjipto (sumber: penulis)

Sejak awal pembangunan, arah kiblat Masjid ini telah diukur oleh Departemen Agama DIY, dan dipastikan kembali oleh Kementrian Agama DIY pada tahun 2012. Pengukuran ini telah menghasilkan keputusan untuk mengarahkan bangunan Masjid yang menyelisihi arah jalan di sekitar Bandar Udara pada umumnya. Hal ini dapat diketahui dari arah bangunan yang sedikit condong ke arah Utara (atau lebih tepatnya ke arah Barat Laut), serta arah bangunan yang tidak sama dengan arah jalan utama Bandar Udara Adisutjipto yang diprioritaskan untuk menghadap ke arah Timur dan Barat.

Dalam masjid ini telah disediakan pakaian shalat yang terdiri dari sarung, sajadah, mukena dan al-Qur'an serta gambar Kakbah sebagai petunjuk arah kiblat. Berdasarkan hal tersebut, tatanan ruang masjid ini tergolong memiliki penataan yang istimewa, karena di dalamnya telah tersedia sarana prasarana lengkap ditambah dengan pengelolaan Masjid yang secara tertib dilaksanakan.

Masjid ini pun memiliki tempat khusus yang digunakan tatkala Jama'ah shalat Masjid Baitul Hidayah melebihi kapasitas yang disediakan, yaitu dengan menggunakan tiang penyangga yang didisain agar mampu melindungi jama'ah dari panasnya terik matahari dan juga air hujan. Tempat khusus ini mampu menampung jama'ah hingga 6 shaf tambahan. Selain itu, telah disediakan pula tempat tinggal bagi Takmir Masjid Baitul Hidayah yang berlokasi tepat di samping tempat Wudhu Masjid agar pengelolaan Masjid Baitul Hidayah lebih mudah dan efektif dengan keberadaan mereka.

Menurut Takmir Masjid Baitul Hidayah, penentuan arah kiblat merupakan hal yang penting. Sehingga tatkala kita hendak menunaikan shalat, sudah sepatutnya kita memperhatikan arah kiblat semampunya agar sesuai dengan apa yang diperintahkan Allah di dalam al-Qur'an. Apabila arah sajadah telah sesuai dengan arah kiblat, maka rasa waswas yang menghinggapi jama'ah terhadap arah kiblat dapat dihilangkan sehingga mampu memberikan rasa khusyu' ke dalam hati mereka dalam beribadah.")

c. Masjid di Mall Plaza ambarrukmo

Plaza Ambarrukmo merupakan salah satu pusat perbelanjaan terbaik di Yogyakarta dan Jawa Tengah yang berlokasi di wilayah strategis, hanya 10 menit dari Bandara Internasional Adisutjipto dengan mobil dan dapat diakses dengan taksi atau transportasi umum lainnya. Berada di kawasan warisan budaya yang kental dengan nilai historis, Plaza Ambarrukmo dibangun dengan perpaduan konsep arsitektur klasik dan desain interior modern ("Sejarah Plaza Ambarrukmo," n.d.).

*) Hasil wawancara dengan Ahmad Ali Afandi, S.Th.I. (Staff Procurement di PT. Angkasa Pura 1 (Persero), Mantan Ketua Takmir Masjid Baitul Hidayah Bandar Udara Adisutjipto) pada tanggal 18 Oktober 2016. 
Mall ini merupakan salah satu dari 3 destinasi wisata warisan terpadu di Yogyakarta yang tergabung dalam istilah "The Ambarrukmo". *)

Di lantai 7 mall ini terdapat sebuah Masjid yang berdiri megah seluas $\pm 18 \mathrm{~m} 2$ X $24 \mathrm{~m} 2$. Masjid ini dirancang oleh Munichy B. Edrees ${ }^{* *}$ dengan arsitektur gaya Mediterania yang merupakan salah satu gaya arsitektur yang cenderung sejuk dengan intensitas matahari sedang dan terpaan angin yang cukup tinggi. Untuk itulah, struktur bangunan Masjid ini dibuat agar tahan di daerah yang berangin seperti di lantai 7 Ambarrukmo Plaza.

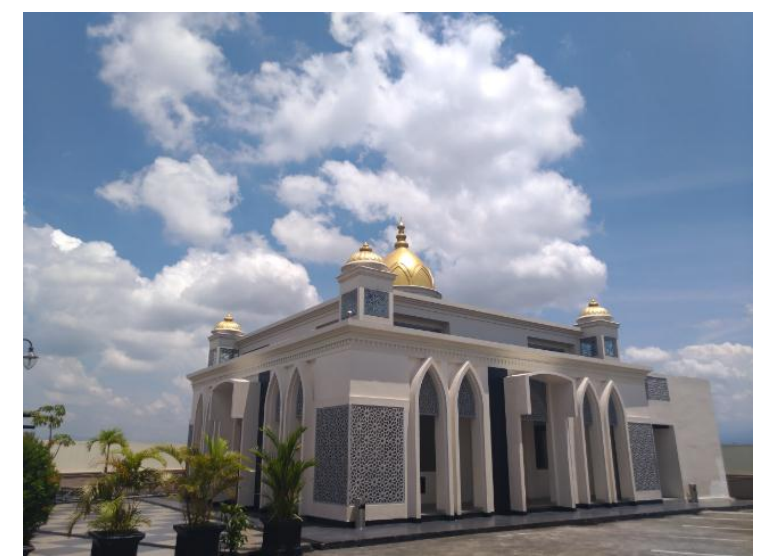

Gambar 3. Masjid Baitul Hidayah Bandara Adisutjipto (sumber: penulis)

"Masjid Plaza Ambarrukmo"
dibangun
pembangunan Ambarrukmo Plaza yang
dimulai sejak tahun 2006 di bawah
pengelolaan PT. Putra Mataram Mitra
Sejahtera yang saat ini dipimpin oleh
Haris Susanto.

Pada awal pembangunannya, Ambarrukmo Plaza mendirikan Masjid di sisi Selatan lantai 7 yang eksis hingga tahun 2011. Namun berhubung jumlah
Jama'ah yang semakin membeludak, akhirnya dibangun kembali Masjid di sisi Utara pada tahun 2011 dengan kapasitas 125-300 Jama'ah yang diresmikan pada tanggal 26 April 2013 untuk menggantikan fungsi Masjid yang ada di sisi Selatan dengan kapasitas dan fasilitas yang lebih bagus.

Kiblat Masjid tersebut sudah diukur sejak awal pembangunannya oleh tim dari Departemen Agama Yogyakarta. Hal tersebut dapat dilihat dari arah bangunan Masjid yang disejajarkan dengan arah kiblat dan tidak mengacu pada arah bangunan Ambarrukmo Plaza yang mengarah ke Barat.

Selain bangunan Masjid, di Ambarrukmo Plaza ini terdapat pula Mushalla di lantai Basement (B), Ground (G), dan lantai 1. Untuk kenyamanan kaum Muslimin dalam beribadah, pengelola Ambarrukmo Plaza sempat merenovasi Mushalla-mushalla tersebut pada tahun 2014. Walaupun arah bangunan Mushalla ini disejajarkan dengan arah bangunan pada Ambarrukmo Plaza, namun shaf pada Mushalla tersebut telah disesuaikan dengan arah kiblat yang semestinya.

Dari sisi pengelolaan, Masjid ini dikelola langsung oleh Chief Engineer Ambarrukmo Plaza yang merangkap sebagai ketua Takmir dan disertai pula oleh Sekretaris Takmir, Bendahara Takmir, dan beberapa staf lainnya. Pengelola "Masjid Plaza Ambarrukmo" sangat selektif dalam memilih Khatib Jum'at, sehingga sangat wajar apabila Jama'ahnya selalu membludak pada saat datangnya waktu shalat Jum'at.

*) The Ambarrukmo terdiri dari 3 destinasi wisata warisan terpadu: Royal Ambarrukmo Yogyakarta, Ambarrukmo Plaza, dan Pesanggrahan Ambarrukmo.

${ }^{* *}$ ) Munichy B. Edrees adalah Ketua umum Ikatan Arsitek Indonesia periode 2012-2015 yang juga mendedikasikan dirinya sebagai dosen di UII (Universitas Islam Indonesia) dan di UMY (Universitas Muhammadiyah Yogyakarta). Selain itu, dia masih sempat menekuni dunia lukis abstractexpressionism yang menjadi hobi dan kecintaannya, serta mengelola galeri lukisan di Yogyakarta. 
Menurut Takmir Masjid Plaza Ambarrukmo yakni Huriptoto Tristiawan, S.T., bahwa berdasarkan pada pengetahuannya menghadap arah kiblat itu bervariasi, berdasar pada pendapat ulama yang berbeda antara yang mengatakan penting untuk menghadap kiblat secara yakin dan benar dengan menghadap kiblat hanya pada arahnya saja. Sehingga ia berkesimpulan untuk mengikuti pendapat ulama yang ada, jika memang satu Masjid sudah pernah diukur artinya tidak ada masalah.*)

Berdasarkan pada hasil wawancara diketahui kecenderungan pola pikir masyarakat dalam hal ini pengelola terhadap arah kiblat Masjid di ruangruang publik. Kecenderungan pemahaman para pengelola dalam hal ini takmir Masjid terhadap kepentingan dalam menghadap kiblat termasuk pada kategori baik, terlihat pada kepedulian mereka dalam mengecek dan memperbaiki arah kiblat yang disesuaikan dengan perkembangan ilmu pengetahuan dan teknologi yang sedang berkembang.

Analisis tentang pemahaman pengelola Masjid terkait arah kiblat di ruang-ruang publik ini dapat dikategorikan pada unsur kebudayaan yang meliputi masyarakat Muslim Yogya pada khusunya. Unsur kebudayaan yang dibahas ini adalah interaksi antara 3 unsur (Sulasman \& Gumilar, 2013) yaitu peralatan dan perlengkapan hidup (teknologi), sistem ilmu dan pengetahuan, dan sistem kepercayaan (religi). Unsur pertama yakni peralatan dan perlengkapan hidup (teknologi) di mana teknologi menjadi salah satu komponen kebudayaan. Teknologi ini mencakup cara-cara atau teknik memproduksi, memakai serta memelihara segara peralatan dan perlengkapan. Teknologi ini muncul dalam cara bagaimana manusia mengorganisasikan masyarakat dan mengekspresikan rasa keindahan, atau dalam memproduksi hasil-hasil kesenian. Dalam konteks penelitian ini manusia memelihara keindahan pada fungsi tempat ibadah supaya terlihat indah dan nyaman yakni memelihara fungsi Masjid sebagai tempat beribadah ketika menghadap Tuhan.

Unsur kedua, yakni sistem ilmu dan pengetahuan, di mana secara sederhana pengetahuan merupakan segala sesuatu yang diketahui manusia tentang benda, sifat, keadaan, dan harapan-harapan. Pengetahuan yang diperoleh berasal melalui pengalaman, intuisi, wahyu dan berpikir baik menurut logika atau percobaan yang bersifat empiris. Dalam konteks penelitian ini, manusia memperoleh sistem ilmu dan pengetahuan terkait ruang dan waktu, yakni pengetahuan geografi dan astronomi yakni dalam konteks kewilayahan dan posisi bagaimana menghadap Kakbah di kota Mekah sebagai arah yang dituju umat Muslim ketika beribadah. Manusia mendapatkan ilmu pengetahuan berupa kesadaran posisi di Indonesia yang mengharuskan umat Muslim menghadap sesuai dengan posisi geografisnya masingmasing.

Unsur ketiga, sistem kepercayaan (religi) dalam hal ini agama Islam. Sistem ini merupakan keyakinan adanya penguasa tertinggi dari sistem jagat raya ini yang mengendalikan manusia sebagai salah satu bagian dari jagat raya,

*) Hasil wawancara dengan Huriptoto Tristiawan, S.T. (Chief Engineer di Ambarrukmo Plaza, sekaligus Ketua Takmir Masjid Plaza Ambarrukmo periode 2013-sekarang) pada tanggal 17 Oktober 2016 
sehingga baik secara individual maupun hidup bermasyarakat, manusia tidak dapat dilepaskan dari religi atau sistem kepercayaan kepada penguasa alam semesta. Sistem religi ini merupakan salah satu unsur universal dari kebudayaan sehingga karakteristik utama religi ini adalah kepercayaan pada kekuatan di luar manusia atau supranatural. Dalam konteks penelitian ini, manusia tidak terlepas dari perintah Agama yakni adanya kewajiban menghadap kiblat ketika beribadah khususnya shalat.

\section{B. Akurasi Arah Kiblat di Ruang Publik}

Kata akurasi dalam kamus Ilmiah populer bermakna kecermatan, ketelitian dan ketepatan (Rais, 2012). Dalam konteks penelitian ini yakni akurasi dikaitkan dengan kata kiblat sehingga bermakna ketetapan sudut kiblat atau arah bangunan Masjid di ruang publik yang mejadi objek penelitian, sehingga diketahui selisih penyimpangan jika setelah dilakukan perhitungan berbeda dengan arah kiblat yang seharusnya.

Pada penelitian ini digunakan alat pengukur kiblat yakni Mizwalla. Mizwalla adalah alat berbentuk lingkaran dengan bidang dial yang memiliki tongkat untuk menangkap bayangan matahari sehingga diperoleh sudut azimuth matahari yang memudahkan pengukur mengetahui arah kiblat secara praktis (Budiwati, 2017). Cara kerja daripada alat ini dikatakan mudah, karena pengukur hanya memutar bidang dial sesuai angka pada program perhitungan dan menarik benang dari pusat tongkat kearah luar bidang dial sesuai dengan bayangan tongkat untuk diketahui arah utara, kemudian setelahnya pengukur mengambil sudut azimuth kiblat pada bidang dial tersebut. Dengan demikian secara praktis, alat ini dapat digunakan pada waktu kapan saja dengan syarat terhadap Matahari sehingga terbentuk bayangan yang dapat membantu menemukan sudut kiblat.

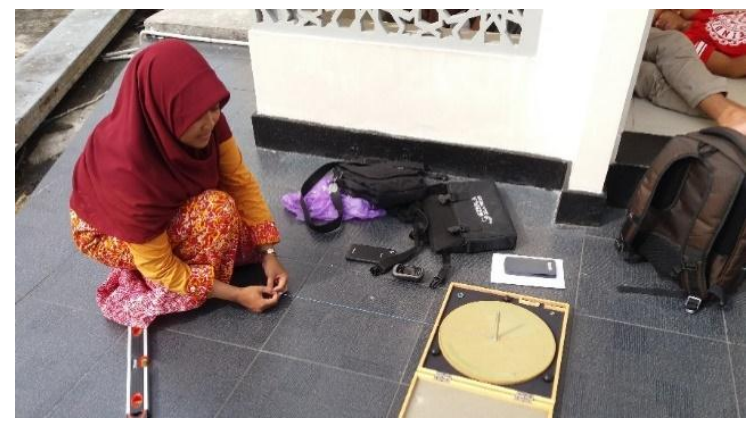

Gambar 4. Mengukur arah kiblat menggunakan Mizwalla (sumber: penulis)

Berdasarkan pada pengukuran arah kiblat Masjid pada tiga tempat yakni Rumah Sakit JIH, Bandara Adisutjipto dan Mall Plaza Ambarrukmo, maka dapat diuraikan akurasi dari arah kiblat ketiga tempat tersebut pada penjelasan berikut ini.

\section{a. Akurasi Kiblat Masjid di Rumah Sakit JIH}

Masjid Rumah Sakit JIH merupakan bangunan publik yang terletak paling depan setelah gerbang masuk di sebelah barat bangunan Rumah Sakit. Masjid Rumah Sakit JIH terletak pada posisi $7^{\circ}$ 45' 28.91" LS dan $110^{\circ} 24^{\prime}$ 8.89" BT.

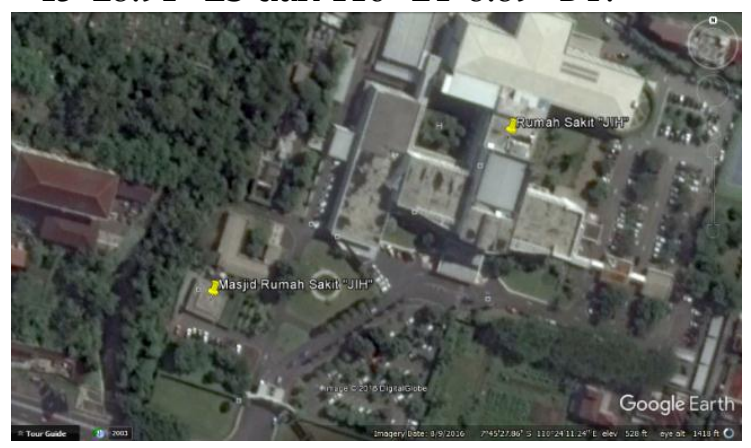

Gambar 5. Mengukur arah kiblat menggunakan Mizwalla (sumber: penulis) 
Arah atau Azimuth kiblat untuk posisi Masjid Rumah Sakit JIH yakni 24o 41' 38,11" (B-U), 65o 18' 21,89" (U-B) dan 294o 41' 38,11" (UTSB). .) Untuk mengetahui akurasi arah kiblat Masjid Rumah Sakit JIH, peneliti melakukan pengukuran menggunakan Mizwalla. Mizwalla dipasang pada tempat datar di sekitar Masjid dengan syarat tersinari cahaya matahari. Dalam posisi tertentu, diperhitungkan arah kiblat berdasarkan input data berupa lintang dan bujur.

Setelah dilakukan pengukuran menggunakan Mizwalla diperoleh nilai penyimpangan Masjid di Rumah Sakit JIH sebesar 0o 01' 20,8" kurang ke selatan pada pengukuran tanggal 2 Oktober 2016 dan pada tgl 25 Desember 2016 diperoleh penyimpangan sebesar 0o 01' 3,42" kurang ke selatan.

\section{b. Akurasi Kiblat Masjid di Bandara Adisutjipto}

Masjid Bandara Adisutjipto merupakan bangunan publik yang terletak di sebelah utara Bandara Adisutjipto. Masjid Bandara Adisutjipto terletak pada posisi $7^{\circ} 47^{\prime} 2.38^{\prime \prime}$ LS dan $110^{\circ} 26^{\prime} 6.98^{\prime \prime} \mathrm{BT}$.

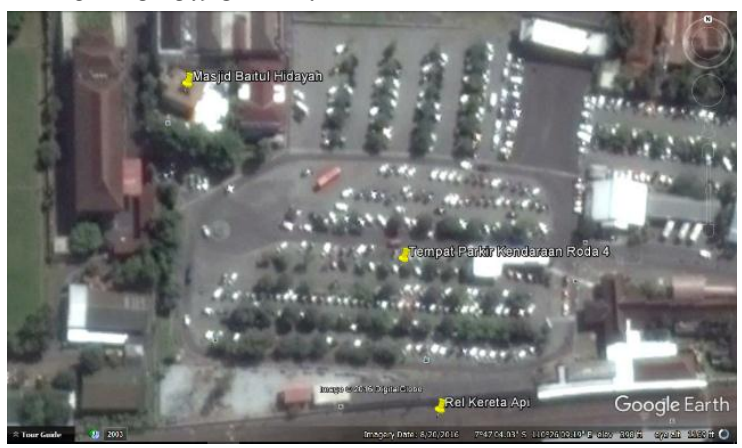

Gambar 6. Mengukur arah kiblat menggunakan Mizwalla (sumber: penulis)

Arah atau Azimuth kiblat untuk posisi Masjid Baitul Hidayah Bandara Adisutjipto yakni 24o 41'31,61" (B-U), 65o 18' 28,39" (U-B) dan 294o 41' 31,61" (UTSB). Untuk mengetahui akurasi arah kiblat Masjid Baitul Hidayah Bandara Adisutjipto, peneliti melakukan pengukuran menggunakan Mizwalla. Mizwalla dipasang pada tempat datar di sekitar Masjid dengan syarat tersinari cahaya matahari. Dalam posisi tertentu, diperhitungkan arah kiblat berdasarkan input data berupa lintang dan bujur.

Setelah dilakukan pengukuran menggunakan Mizwalla diperoleh nilai penyimpangan Masjid di Rumah Sakit JIH sebesar 0o 00' 56,04" kurang ke selatan pada pengukuran tanggal 25 Desember 2016 dan pada tgl 22 Januari 2017 diperoleh penyimpangan sebesar 0o $00^{\prime} 56,01^{\prime \prime}$ kurang ke selatan.

\section{c. Akurasi Kiblat Masjid di Mall Plaza Ambarrukmo}

Masjid Plaza Ambarrukmo merupakan bangunan publik yang terletak di atap bagian utara Mall Ambarrukmo Plaza. Masjid Plaza Ambarrukmo terletak pada posisi $7^{\circ} 46^{\prime} 53.21^{\prime \prime}$ LS dan $110^{\circ} 24^{\prime} 4.18^{\prime \prime}$ BT.

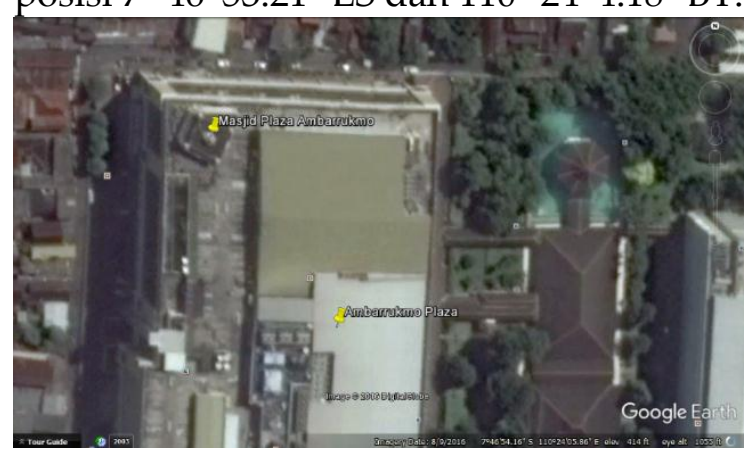

Gambar 7. Bangunan Masjid Plaza

Ambarrukmo (sumber: Google Earth)

Arah atau Azimuth kiblat untuk posisi Masjid Baitul Hidayah Bandara Adisutjipto yakni 24o 41' 59,55" (B-U), 65o 18'0,45" (U-B) dan 294o 41' 59,55" (UTSB).

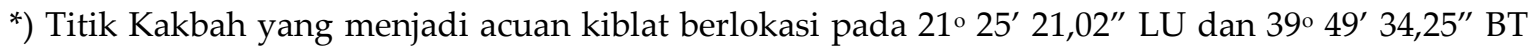
sebagaimana pengambilan titik center pada program Google Earth oleh penulis. Aplikasi penggunaan Google Earth dapat dibaca lebih lengkap di buku berjudul Google Earth (Yousman, 2008). 
Untuk mengetahui akurasi arah kiblat Masjid Plaza Ambarrukmo, peneliti melakukan pengukuran menggunakan Mizwalla. Mizwalla dipasang pada tempat datar di sekitar Masjid dengan syarat tersinari cahaya matahari. Dalam posisi tertentu, diperhitungkan arah kiblat berdasarkan input data berupa lintang dan bujur.

Setelah dilakukan pengukuran menggunakan Mizwalla diperoleh nilai penyimpangan Masjid di Rumah Sakit JIH sebesar 0o 00' 59,68" kurang ke selatan pada pengukuran tanggal 22 Januari 2017 dan pada tgl 5 Maret 2017 diperoleh penyimpangan sebesar 0o 01' 6,54" kurang ke selatan.

Dari pendataan perhitungan di lapangan diperoleh kesimpulan bahwa sekalipun memiliki penyimpangan yang lebih kecil dari 1 derajat, maka penyimpangan 1 menit busur mencapai 2 km dari Kakbah. Perhitungan detail dapat dilihat pada tabel berikut ini.

\begin{tabular}{|c|c|c|c|}
\hline Lokasi & Tanggal Pengukuran & Sudut penyimpangan & Jarak Penyimpangan \\
\hline \multirow[t]{2}{*}{1} & 2 Oktober 2016 & $0^{\circ} 01^{\prime} 20,8^{\prime \prime}$ kurang ke selatan & 3,074 km dari Kakbah \\
\hline & 25 Desember 2016 & $0^{\circ} 01^{\prime} 3,42^{\prime \prime}$ kurang ke selatan & 2,413 km dari Kakbah \\
\hline \multirow[t]{2}{*}{2} & 25 Desember 2016 & $0^{\circ} 00^{\prime} 56,04^{\prime \prime}$ kurang ke selatan & 2,133 km dari Kakbah \\
\hline & 22 Januari 2017 & $0^{\circ} 00^{\prime} 56,01^{\prime \prime}$ kurang ke selatan & 2,132 km dari Kakbah \\
\hline \multirow[t]{2}{*}{3} & 22 Januari 2017 & $0^{\circ} 00^{\prime} 59,68^{\prime \prime}$ kurang ke selatan & 2,271 km dari Kakbah \\
\hline & 5 Maret 2017 & $0^{\circ} 01^{\prime} 6,54^{\prime \prime}$ kurang ke selatan & 2,532 km dari Kakbah \\
\hline
\end{tabular}

Tabel 1. Penyimpangan sudut kiblat Masjid di Ruang Publik

Sumber : hasil perhitungan penulis*) , Ket. 1 = Masjid di RS JIH, 2 = Masjid di Bandara Adi Adisutjipto dan 3 = Masjid di Mall Plaza Ambarrukmo

Dengan demikian dapat diperoleh kesimpulan bahwa tiga Masjid yang berada di ruang publik seperti Rumah Sakit, Bandara dan Mall termasuk pada kategori akurat dengan alasan tidak mencapai selisih penyimpangan 1 derajat. Satu derajat menjadi minimal akurasi dari penelitian ini dikarenakan penyimpangan yang disebabkan tidak mengakibatkan arah ke arah Kakbah keluar dari Mekah.
Untuk menjelaskan akurasi satu derajat ini, penulis membuat batas-batas pada kota Mekah dengan tanda nomor 1 sampai dengan 6 untuk dapat diketahui batasan azimuth kiblat jika dihitung dari salah satu Masjid di Ruang Publik di Kabupaten Sleman Yogyakarta misalnya Masjid Baitul Hidayah Bandara Adisutjipto Yogyakarta.

*) Sudut penyimpangan diperoleh dari hasil tangen derajat penyimpangan dikali dengan jarak. Sedangkan untuk jarak diperoleh dari hasil pembagian (perkalian jari-jari Bumi $(6372,65 \mathrm{~km})$, selisih bujur Kakbah dan tempat dan nilai phi sebesar 3,141592654) dengan $180^{\circ}$. 


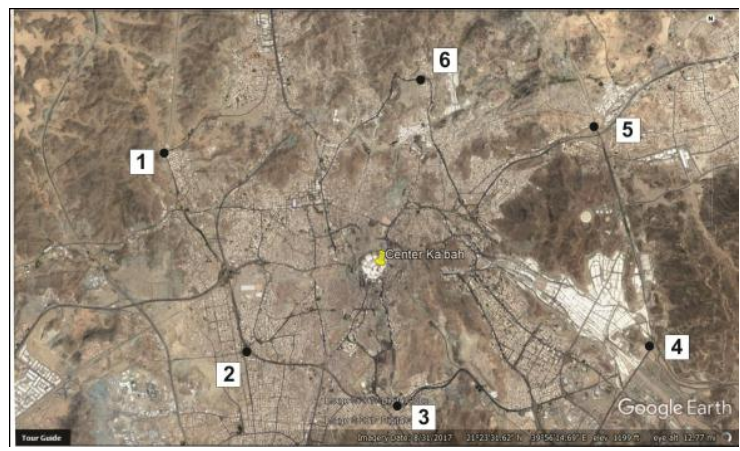

Gambar 8. Titik-titik batas kota Mekah sebagai acuan perbandingan kiblat (sumber: Google Earth dimodifikasi penulis)

Kemudian dihitung berapa azimuth kiblatnya sebagaimana tabel berikut ini.

\begin{tabular}{|c|c|c|c|}
\hline Titik & Lintang & \multicolumn{1}{|l|}{ Bujur } & Az Bandara ke Titik ${ }^{*}$ \\
\hline 1 & $21^{\circ} 27^{\prime} 22,16^{\prime \prime}$ & $39^{\circ} 45^{\prime} 36,04^{\prime \prime}$ & $294^{\circ} 42^{\prime} 34,41^{\prime \prime}$ \\
\hline 2 & $21^{\circ} 24^{\prime} 2,51^{\prime \prime}$ & $39^{\circ} 47^{\prime} 5,61^{\prime \prime}$ & $294^{\circ} 39^{\prime} 36,62^{\prime \prime}$ \\
\hline 3 & $21^{\circ} 23^{\prime} 2,46^{\prime \prime}$ & $39^{\circ} 49^{\prime} 59,98^{\prime \prime}$ & $294^{\circ} 39^{\prime} 19,28^{\prime \prime}$ \\
\hline 4 & $21^{\circ} 24^{\prime} 4,98^{\prime \prime}$ & $39^{\circ} 54^{\prime} 37,84^{\prime \prime}$ & $294^{\circ} 41^{\prime} 30,12^{\prime \prime}$ \\
\hline 5 & $21^{\circ} 27^{\prime} 47,64^{\prime \prime}$ & $39^{\circ} 53^{\prime} 38,17^{\prime \prime}$ & $294^{\circ} 44^{\prime} 58,25^{\prime \prime}$ \\
\hline 6 & $21^{\circ} 28^{\prime} 38,34^{\prime \prime}$ & $39^{\circ} 50^{\prime} 24,79^{\prime \prime}$ & $294^{\circ} 45^{\prime} 1,44^{\prime \prime}$ \\
\hline
\end{tabular}

Tabel 2. Azimuth titik-titik batas kota Mekah dari Masjid Bandara Adisutjipto Yogyakarta 
Diskusi

Penelitian ini memiliki kebaruan pada analisis pemahaman pengelola tempat ibadah terkait arah kiblat di ruang-ruang publik dan akurasi kiblatnya. Sejauh penelusuran penulis, penelitian tentang kiblat di ruang publik belum banyak dibahas, mayoritas penelitian yang terkait dengan arah kiblat berbicara pada arah kiblat pada Masjid-Masjid Kuno di daerah Indonesia atau membahas tentang perubahan kiblat dan pergeseran Lempeng Bumi Perspektif Syari'ah dan Ilmiah (Wahidi, Ahmad, \& Nuroini, 2010). Penelitian lainnya terkait ruang publik lebih fokus pada pola tempat ibadah sebagai kegiatan umat Beragama dan lebih pada penggalian morfologi arsitektur Masjid (Iskandar, 2004).

Mayoritas penelitian sebelumsebelumnya cenderung pada bahasan yang berhubungan dengan arah kiblat Masjid dan khusus arsitektur Masjid, sedangkan penelitian yang dilakukan oleh peneliti adalah analisis pemahaman para pengelola khususnya di Masjid yang ada di ruang publik terkait pentingnya menghadap arah kiblat sekaligus mengetahui akurasi dari masjid-masjid tersebut. Penelitian ini memberi tekanan pada upaya menemukan aspek standar arah kiblat yang seharusnya diterapkan pada tempat ibadah Masjid di ruangruang publik dengan memberikan penalaran berapa penyimpangan Masjid yang ada di tuang publik.

Persoalan pertama yang dibahas yakni pola pemahaman pengelola Masjid tidak lain dapat dilihat dari perspektif teori kebudayaan, di mana kecenderungan positif terhadap pentingnya arah kiblat merupakan hubungan unsur-unsur kebudayaan. Hal ini ditunjukan secara jelas pada bagaimana respon pengelola terhadap pentingnya menghadap arah kiblat ketika Masjid dibangun untuk pertama kalinya, maupun ketika Masjid dilakukan perubahan dan perluasan. Pola pemahaman para pengelola ini tidak lain disebabkan adanya integrasi tuntunan agama, pengetahuan ilmu geografi dan astronomi, serta tuntutan perawatan maupun perubahan pada desain Masjid sebagai tempat ibadah yang akan sering sekali dikunjungi publik umumnya.

Dari hubungan unsur-unsur kebudayaan kemudian dihubungkan dengan hasil wawancara, dapat diketahui interaksi tiga unsur kebudayaan yang membentuk pola pemahaman pengelola Masjid di ruang publik, khususnya di Rumah Sakit, Bandara dan Mall. Kecenderungan pola pemahaman tentang menghadap kiblat di Yogyakarta, Kabupaten Sleman khususnya ini tidak lain dipengaruhi oleh berbagai faktor, di antaranya geografis, di mana setiap unsur kebudayaan yang telah penulis jelaskan sebelumnya akan selalu berubah sesuai dengan tingkat kebutuhan masyarakat dan proses adatif yang diperlukan.

Analisis akurasi melalui perhitungan dan pengukuran arah kiblat pada 3 tempat tersebut menunjukan ketelitian yang memadai karena ketelitiannya mencapai 0o 5' 42,16" atau dibulatkan menjadi 6 menit, sehingga penyimpangan arah kiblat Masjid di ruang publik ini 2 menit atau setara dengan $3 \mathrm{~km}$ yang berarti masih dalam cakupan kota Mekah (tidak sampai keluar dari batas kota Mekah). Dari hasil penelitian ini, akurasi kiblat pada mayoritas Masjid di Yogyakarta dapat disimulasikan dengan jika azimuth kiblat Yogyakarta terlalu utara yakni mencapai 295o ataupun 1 derajat terlalu ke selatan yaitu 296o, maka ukuran 1 derajat adalah batas di mana kiblat keluar dari kota Mekah. Sebagaimana perhitungan yang sudah dilakukan penulis pada pembahasan hasil. Dengan demikian, sampel pada penelitian ini menunjukan 
adanya kualitas hidup Islami umat muslim di Kabupaten Sleman Yogyakarta yang tercermin pada akurasi tempat ibadah yakni Masjid yang berada di ruang publik seperti di Rumah Sakit JIH, Bandara Adisutjipto dan Mall Plaza Ambarrukmo.

Analisis akurasi kiblat yang dijelaskan pada penelitian ini tidak lain sebagai bukti penguat bahwa pemahaman pengelola atau takmir Masjid di Ruang Publik telah sangat memenuhi syarat masyarakat yang memiliki kualitas hidup Islami. Ruang publik yang memiliki Masjid dengan ketelitian arah kiblat yang baik menunjukkan adanya konsep pemahaman yang baik pula. Hal ini mengingat masyarakat perkotaan dikenal sebagai masyarakat yang cenderung pada minimnya pemahaman agama, namun pada kenyataanya ternyata terbukti sebaliknya.

\section{PENUTUP \\ Kesimpulan}

Penelitian ini menghasilkan kesimpulan, kecenderungan pola pikir masyarakat perkotaan terkait arah kiblat tempat ibadah di ruang publik di Kabupaten Sleman termasuk pada pemahaman yang baik sebagai model kualitas hidup Islami yang tercermin pada Masjid yang dimiliki Rumah Sakit JIH, Bandara Adisutjipto dan Mall Plaza Ambarrukmo. Pentingnya menghadap arah kiblat ditunjukan dari adanya pengukuran permanen yang dilakukan ketika mendirikan bangunan, juga perawatan lanjutan berupa pengukuran dan pengecekkan arah kiblat kembali ketika bangunan diperluas. Meskipun pengetahuan pengelola atau takmir Masjid termasuk pada kategori awam, namun pentingnya menghadap kiblat sudah menjadi pengetahuan yang mendorong mereka untuk berusaha meluruskan kiblat.

Kemudian berdasarkan perhitungan trigonometri bola dan pengukuran arah kiblat menggunakan Mizwalla diperoleh kesimpulan bahwa arah kiblat tempat ibadah di ruang publik yaitu di Rumah Sakit, Bandara dan Mall tergolong cukup akurat yakni dengan selisih penyimpangan paling besar sebanyak $0 \mathrm{o}$ 1' 20,8' atau setara dengan 3,074 $\mathrm{km}$ masih dalam wilayah kota Mekah. Hal ini didasarkan pada perhitungan azimuth dengan sampel Masjid di ruang publik terhadap enam titik di batas kota Mekah sehingga diperlukan ketelitian sekitar 6 menit agar menghadap setidak-tidaknya ke kota Mekah.

\section{DAFTAR PUSTAKA}

Al-Qurtuby, I. R. (n.d.). Bidayat alMujtahid wa Nihayat al-Muqtashid (Juz. 1). Beirut: Dar al-Fikri.

Anita, J., Gustya, F., Erawati, L. R., \& Sukma, M. D. (2012). Kajian Terhadap Ruang Publik Sebagai Sarana Interaksi Warga di Kampung Muararajeun Lama , Bandung, (I), 1-12.

BPS. (2015). Penduduk Provinsi Daerah Istimewa Yogyakarta Hasil Sensus Penduduk 1961-2010. https://doi.org/2102001.34

Budiwati, A. (2015). Model Pembelajaran Integratif Dalam Pengajaran Matakuliah Ilmu Falak I I Di Program Studi Hukum Islam. In Proceeding of International Conference on Integration of Contemporary and Islamic Knowledge in Islamic Universities.

Budiwati, A. (2017). Teori dan Aplikasi Ilmu Falak di Perguruan Tinggi Islam. Yogyakarta: Universitas Islam Indonesia.

Carmona, M., Tiesdell, S., Carmona, M., \& Heath, T. (2003). Public Places Urban Spaces. Oxford: Architectural Press. 
Goenawan, R. dan D. H. (2012). Mobilitas Sosial Daerah Istimewa Yogyakarta Periode Awal Abad ke- 20: Suatu Kajian Sejarah Sosial. Yogyakarta: Ombak (Anggota IKAPI).

Hakim, L., Raharjo, R. B., \& Waluyo, D. D. (2013). Prototype Robot untuk Menentukan Arah Kiblat dengan Tanda Shaf (pp. 1-8). Retrieved from

http://artikel.dikti.go.id/index.php/ PKMKC/article/view/211

Iskandar, M. S. B. (2004). Tradisionalitas dan Modernitas Tipologi Arsitektur Masjid. DIMENSI (Journal Architecture and Built Environment), 32(2), 110-118. https://doi.org/https://doi.org/10.97 44/dimensi.32.2.

Izzuddin, A. (2012). Ilmu Falak Praktis (Metode Hisab-Rukyat Praktis dan Solusi Permasalahannya). Semarang: PT. Pustaka Rizki Putra. Jaelani, Ahmad, dkk. (2012). Hisab Rukyat Menghadap Kiblat (Fiqh, Aplikasi Praktis, Fatwa dan Software)). Semarang: PT. Pustaka Rizki Putra.

Kaelan. (2010). Metode Penelitian Agama Kualitatif Interdisipliner dengan Ilmu Lain. Yogyakarta: Paradigma.

Khazin, M. (2004). Ilmu Falak dalam Teori dan Praktik (Cet.I). Yogyakarta: Buana Pustaka.

Kresnadjaja, W. G., \& Muttaqien, I. (2014). Menentukan Arah Kiblat Mushala Fakultas Saintek UIN Bandung Menggunakan Kompas Kiblat Digital, 1(1), 149-150. Retrieved from

http://journal.uinsgd.ac.id/index.ph p/ahjop/article/view/131/pdf_4

Rais, H. E. (2012). Kamus ilmiah populer : memuat berbagai kata dan istilah dalam bidang politik, sosial, budaya, sains dan teknologi, psikologi, kedokteran, pendidikan
(Cet. 1.). Yogyakarta: Pustaka Pelajar.

Ratna, N. K. (2010). Metodologi Penelitian: Kajian Budaya dan Ilmu Sosial Humaniora pada Umumnya. Yogyakarta: Pustaka Pelajar.

Sejarah Bandara Internasional Adisutjipto Yogyakarta. (2015). Retrieved from https://www.ap1.co.id/id/about/ou r-history

Sejarah Plaza Ambarrukmo. (n.d.). Retrieved from https://www.plazaambarrukmo.co.id/about.php

Sejarah Rumah Sakit JIH. (2013). Retrieved from http://www.rsjih.co.id/tentang

Smart, W. . (1977). Textbook on Spherical Astronomy. New York: Cambridge University Press. 